\title{
The Cambridge History of Classical Literature
}

Volume II: Latin Literature

\section{Edited by E. J. KENNEY and W. V. CLAUSEN}

First published in one hard cover volume, Latin Literature is now available in five paperback volumes, divided chronologically. Each volume includes the relevant sections of the appendix of authors and works and the metrical appendix, and has its own bibliography and index.

\section{Part 1: The Early Republic}

An analysis of the process of creative adaptation which shaped the beginnings of Latin literature, from the middle of the third century $\mathrm{BC}$, when the first Latin play took the stage, to $100 \mathrm{BC}$, when most of the important genres invented by the Greeks were solidly established in their adoptive Roman forms and a new genre, satire, had been born.

Paperback $£ 7.50$ net

\section{Part 2: The Late Republic}

The contributors to this volume show how Roman writers of genius, such as Lucretius, Sallust, Caesar and, in particular, Cicero and Catullus, continued the process of transforming their traditional Greek models into the new and vigorous Latin forms that were to have lasting effects for oratory,

historiography and the higher genres of poetry.

Paperback $\mathbf{E 6 . 5 0}$ net

\section{Part 3: The Age of Augustus}

In this volume the contributors illustrate how Augustan literature, (notably that of Horace, Ovid and Virgil), conventionally viewed as the expression in writing of the age itself - political and social stability reflected in artistic equilibrium turns out on a close and critical reading to have been subject to the same stresses and strains as the society in and for which it was produced.

Paperback $\mathbf{E 7 . 5 0 ~ n e t ~}$

\section{Part 4: The Early Principate}

This volume offers a detailed portrait of an age that was of necessity becoming increasingly more conscious of the past and of the problems of coping with its cultural heritage. Special reference is made to Lucan, Seneca, Statius, Juvenal and Tacitus together with the minor poets and prose writers whose varied activity complements these central figures, giving the age its special character and atmosphere.

Paperback $£ 7.50$ net

\section{Part 5: The Later Principate}

Part Five shows how, as Christianity emerged to become the official religion, the old pagan culture, the staple literary diet of the leisured classes, had to coexist and indeed to compete with a new, specifically Christian-oriented literature. The chapters in this volume illustrate how these and associated developments are reflected in the Latin books of the period.

Paperback 86.50 net

\section{CAMBRIDGE UNIVERSITY PRESS}

